\title{
A TÁRSAS BEFOLYÁSOLÁS FOLYAMATA AZ INFORMÁCIÓS RENDSZEREK HASZNÁLATÁNAK KIALAKULÁSA SORÁN
}

A bevezetett IT-rendszerek valós használata egy hosszabb társas konstrukciós folyamatban alakul ki, melyben a felhasználók és a rendszer kölcsönösen formálják egymást (Bartis 2014). E társas konstrukciós folyamatban bizonyos felhasználók befolyásolják az adott környezetben kialakuló rendszerhasználatot. Jelen cikkben ezt a szerepet és szereplőket tanulmányozza a szerző. Célja, hogy az információs rendszerek tényleges használatának kialakulását jobban megértse.

\section{Kulcsszavak: IT-rendszerek, IT-rendszerek használata, IT-szakértő}

Több szerző és több kutatás foglalkozott már egyes egyéni felhasználók befolyásoló szerepével a rendszerbevezetést követő időszakban. A társas befolyásolás témaköre egészen Salancik és Pfeffer 1977-es kutatásáig nyúlik vissza (Thomas - Griffin, 1983), ahol a szerzők megállapítják, hogy a munkafeladatok pontos értelmezésének kialakulása egy szociális folyamat, melyet több tényező befolyásol. Pfeffer 1981-es cikkére hivatkozva (ibid, p. 5.) kijelentik, hogy egyrészt a többi munkatárs munkafeladat-értelmezése befolyásolja az egyéni értelmezést, másrészt a társas környezet megítélése, attitüdje is befolyásoló hatású.

Ezekre a megállapításokra építve, az információs rendszerek használatára fókuszálva is kérdezhetjük: hogyan alakul ki az egyes egyének feladatértelmezése? A társas környezet vonatkozásában több kutató azonosított szerepeket, melyek befolyásolják az egyéni használatot. A Culnan (1983) által leírt soförök (chauffeurs) információt nyújtanak a többi felhasználónak, ezzel segítik a rendszer használatának megértését. A guruk hozzáértő felhasználók (Bjorn-Anderssen és társai, 1986), akiknek az alaposabb értése segíti a többiek rendszerhasználatát. A Mackay (1990) által fordítóknak (translators) nevezett felhasználók magyarázatokkal segítenek a rendszerértelmezés kialakításában. Lényeges kiemelni, hogy a fent azonosított szerepeket mind informálisan töltik be a hozzáértő felhasználók és hatáskörük lokális.

Később a társas befolyásolás folyamatát igyekeztek a szervezetek aktívan kihasználni. A kutatások rámutattak arra, hogy a tudatosan „beépített” helyi segítők jelentősen fellendítik a rendszerek elfogadottságát (Soo és társai 2009), segíthetnek egyes újítások elterjesztésében (Hendy - Barlow, 2012), az ellenállás leküzdésében (Gerow - Rhamey, 2014), illetve ennek közvetett eredményeként fellendítik a kifejlesztett rendszerek értékesítését is (Obal - Ibrahim, 2016). A szakirodalomban bajnokoknak (champions) nevezett szereplök sikerének kulcsa, hogy a hivatalos hierarchiát figyelmen kívül hagyva tudják a rendszerek használatát segíteni, befolyásolni (Dobson és társai, 2010). Bajnokok beépítése, „kinevezése” a projektmenedzsment egyik általánosan elterjedt eszköze is lett (Kerzner, 2013; Atkinson és társai, 2006).

A bajnok fogalmának korai meghatározása (Howell - Higgins, 1990) szerint a bajnok eredetileg spontán és informálisan veszi fel ezt a szerepet, aktívan és elkötelezetten közvetíti az újítás és változás bevezetését a szervezet többi tagja felé - a szervezet jobbítása érdekében. Más szerzők is foglalkoznak a bajnokok jellemzőivel: Stuart és társai (2009) leírásában lelkes, energikus, elismert, elkötelezett és kockázatvállaló kollégákról van szó. Woodford (2014) pedig azt emeli ki, hogy mind tudásban, mind készségekben a bajnokok értenek az adott technológiához, felismerik a potenciális hasznát és meggyőzően ajánlják azt a szervezetben. Ezek alapján a bajnokoknak a megfelelő készségek mellett pozitív hozzáállással is kell rendelkezniük (Woodford, 2014, p. 3.).

Korábbi kutatásommal összhangban jelen cikkemben azt a szerepet tárom fel részletesebben, ahol a befolyásolás nem szervezetten, tervezetten zajlik, hanem a spontán segítőkészség a megoldások kiváltó oka 
(Bartis, 2014; Ferneley - Sobreperez, 2006). Az általam feltárt esetekben a személyek, akik egyértelmüen segítették és kisebb vagy nagyobb mértékben befolyásolták a vállalatirányítási rendszerek használatát, nem voltak elkötelezett előmozdítói a rendszer bevezetésének. Egyikről sem mondható el, hogy kifejezetten lelkesedett volna az új technológia iránt, vagy használatát ajánlotta volna kollégáinak. A hangsúly sokkal inkább az okos megoldások keresésén, a segíteni akaráson, a fogások tanításán volt mindkét vállalatnál és mind a négy általam azonosított személynél, akik a rendszerek használatát meghatározóan befolyásolták.

Jelen kutatás esetében tehát egy olyan kategóriára van szükség, melyben:

a. a felhasználók hozzáértők és befolyásolják mások rendszerhasználatát,

b. nem a döntéshozók döntése alapján kerültek ebbe a helyzetbe (mint például a fent leírt bajnokok),

c. formálisan is elismert a szerepük és hozzáértésük a rendszerek kapcsán (azaz magasabb szintü jogosultságaik vannak).

Ezeknek a kritériumoknak Orlikowski és társai (1995) által bevezetett kategória bizonyul a legmegfelelöbbnek: az úgynevezett technológiamediátorok (technology mediators). E felhasználók rendszerértelmezése és -használata meghatározza, illetve döntően befolyásolja az ö környezetük - azaz a szervezet technológiahasználatát. A mediátorok segítik a környezetükben lévő felhasználók rendszerértelmezését és ezáltal befolyásolják, hogy a technológia milyen módon válik a környezet részévé - de ezt nem formális, hanem informális szerepként teszik.

\section{A kutatási kérdés}

Mindezek alapján a kutatási kérdést így fogalmazhatjuk meg: hogyan befolyásolja egyes hozzáértő felhasználók rendszerértelmezése a kialakuló használatot az információs rendszer bevezetése során?

Az általam vizsgált technológiamediátorok szerepének megértéséhez Birkinshaw, Hamel és Mol (2008) szempontrendszerét használom. A szerzők szerint a változások elősegítésében (mint amilyennek egy új informatikai rendszer bevezetése minősül (Dobák, 1996)) a változást vezetőknek (elősegítőknek, befolyásolóknak) négyféle feladatuk van:

1. mások motiválása - mások számára olyan körülményeket teremteni, hogy kipróbálják, használják a rendszert,

2. az új gyakorlatokkal kísérletezni - kipróbálni a lehetőségeket, kísérletezni velük,
3. bevezetés - az a gyakorlati folyamat, melynek során egyes folyamatokat és struktúrákat kialakítanak és bevezetnek,

4. az újítás értelmezése - társas folyamat, mely során a bajnokok segítik a társas értelmezés kialakulását.

Az általam vizsgált két vállalati helyszínen az azonosított technológiamediátorok szerepét vizsgálom aszerint, hogy mennyiben töltik be a fent bemutatott szerepeket.

\section{A kutatás}

A kutatást két nemzetközi hátterü, Magyarországon zöldmezős beruházásként létrehozott vállalatnál végeztem. A két vállalatot Bétának (profilja autóipari beszállító), illetve Gammának (profilja fémalkatrész-nagykereskedő) neveztem el.

A kutatás során három különböző időpontban készítettem interjúkat: 2008-ban, 2011-ben és 2014-ben, összesen 40 félig strukturált interjút 27 különböző interjúalannyal. A gyüjtött adatokat a félig strukturált interjúk mellett megfigyelés, beszélgetések, vállalati dokumentumok, körbevezetések is gazdagították. Az interjúalanyokat monogramjukkal és pozíciójuk megnevezésével jelölöm.

\section{A vállalatok és rendszerek leírása}

Az alábbiakban röviden bemutatom először a Béta, majd a Gamma vállalatokat és vállalatirányítási rendszereiket.

A BÉTA vállalat autóipari beszállító, zöldmezős beruházásként 2006-ban épült gyártócsarnokában immár öt gyártósor múködik. Vállalatirányítási rendszerét az alapításkor vezették be, a nemzetközi cégcsoporton belül második termelő helyszínként. Ennek következményeként a vállalatcsoporton belül nem volt jelentősebb tudás a rendszer paraméterezéséről, testreszabásáról, Magyarországon pedig nem volt elérhető az autóipar-specifikus tanácsadói tudás ehhez a rendszerhez. A rendszer bevezetése tréning és oktatási anyagok nélkül történt: „Az első tesztmüvelet már élesben ment” (-S. T. projektmérnök), vagy „Nem kaptunk semmiféle (leírást) arról, hogy hogyan kellene használni a rendszert" (-H. I. projektmérnök vezetö).

A hozzáférési jogokat nem szabályozták, így minden felhasználónak rendszergazda-jogosultsága volt. A paraméterezés pedig teljességgel esetleges volt: az egyes tranzakciók hatásai nem kerültek megfelelő leképezésre a többi kapcsolódó vállalati funkcionális egységnél - a pénzügy, a logisztika, a raktározás, a gyártás funkciók nem voltak összekapcsolva! 
Mivel Béta autóipari beszállító, ezért nagyon szigorú és kialakult standardok vonatkoznak a cégre - viszont az anyavállalat nem támogatta a meglévő modulok bővítését, vagy fejlesztését, így a rendszer egyáltalán nem segítette a napi operációt és a döntéshozókat.

A rendszert így nem is igazán használták Bétánál, hiszen az adatok nem voltak megbízhatóak, a folyamatok nem müködtek, és kezdetben a legtöbb mủvelet, kalkuláció elvégezhető volt papíron, fejben, vagy valamilyen táblázatkezelő programban.

\section{„, A kezdeti idökben S. T. fejében egy MRP-rend- szer müködött. Tudta, hogy melyik alkatrészt honnan vesszük, mennyibe kerül és az aktuális szállítmány éppen hol tart..."}

(Béta ügyvezető igazgatója)

Az anyavállalat számára a problémák legelőször érthető módon a pénzügyi zárások kapcsán jelentkeztek. A rendszeres havi zárások rendre több napot vettek igénybe, a cég a kirendelt belső auditon, majd ellenőrző auditon is megbukott. A megbízott tanácsadók javaslata a teljes ERP-rendszer újrabevezetése volt, az alapoktól, melyet az anyavállalat erőteljesen támogatott. A döntés értelmében újraépítették az ERP-rendszert, majd egy többkörös tesztelést és egyhavi párhuzamos müködést követően lekapcsolták a korábbi rendszert.
„Azt a három srácot delegáltam a projektcsapatba, akik kivül-belül ismerték a rendszert és itt voltak a kezdetektöl fogva."

(Béta ügyvezető igazgatója)

Az újrabevezetés eredményeképpen 2009. februárjától a vállalatirányítási rendszer szolgáltatja az alapadatokat az összes kalkulációhoz. Ehhez erőteljes kultúra- és attitüdváltásra volt szükség, melyet az ügyvezető kitartó és következetes követelményekkel és akciókkal ért el. A rendszer azóta kisebb belső fejlesztésekkel és több rendszer melletti rutinnal jól szolgálja a gyártási folyamatokat

A GAMMA vállalat 2004-ben alakult egy világméretủ multinacionális vállalat magyarországi leányvállalataként. A Gamma fő profilja a fémalkatrész-nagykereskedelem, fö ügyfelei ipari gyártóvállalatok.

A nagykereskedelmi tevékenység eredményeképpen mind a beszerzői, mind az értékesítői oldalon nagyszámú tranzakció zajlik le a vállalatnál. Az egyes munkavállalók heti szinten egy-egy vevőért felelősek és minimum 250, néha akár 1000 nyitott tranzakcióval is dolgoznak. A munkavállalók alapvető fókusza a tranzakciók végrehajtása az elöírt folyamat szerint. A beszerzési, raktározási és értékesítési tevékenységek mellett csak néhány logisztikailag összetettebb szolgáltatást (például csomagolás, méretre vágás) végez a vállalat.

\section{Vállalati igények és felhasználói panaszok áttekintése}

\begin{tabular}{|c|c|}
\hline \multicolumn{2}{|c|}{ BÉTA VÁLLALAT } \\
\hline Vállalati igények & Felhasználói panaszok \\
\hline $\begin{array}{l}\text { Megbízható, pontos számítások (alapanyag-igény, gyártási } \\
\text { terv, kiszállítások, raktározás) }\end{array}$ & Gyártási terv csak heti szinten készíthető \\
\hline Rendelések ütemezése & Ömlesztett anyagok utánrendelése problémás \\
\hline Több valutaárfolyam beállítása dátum szerint & $\begin{array}{l}\text { Egyetlen valutaárfolyam adható meg, így } \\
\text { maradványösszegek keletkeznek }\end{array}$ \\
\hline $\begin{array}{l}\text { Elektronikus kapcsolat a megrendelők informatikai } \\
\text { rendszerével (autóipar) }\end{array}$ & $\begin{array}{l}\text { Raktári rendszer nem dinamikus, a kiszállítások } \\
\text { idôpontjának megadása nem rugalmas }\end{array}$ \\
\hline Standard riportok futtatása & \\
\hline \multicolumn{2}{|c|}{ GAMMA Vállalat } \\
\hline $\begin{array}{r}\text { Vállalati igények } \\
\end{array}$ & Felhasználói panaszok \\
\hline $\begin{array}{l}\text { Jól áttekinthető listák, szúrés funkció, megjegyzések, } \\
\text { színkódok lehetôsége - a megrendelések kezeléséhez }\end{array}$ & $\begin{array}{l}\text { Adatok szúrése, sorba rendezése a rendszeren belül } \\
\text { bonyolult }\end{array}$ \\
\hline $\begin{array}{l}\text { Vevő szerint szúrhető státuszriport készítése } \\
\text { Gyors rendszer vevői kapcsolattartáshoz }\end{array}$ & Lassú rendszer \\
\hline $\begin{array}{l}\text { Egy cikkszámhoz több ár hozzárendelése, illetve } \\
\text { darabszámtól függő árak bevitele }\end{array}$ & $\begin{array}{l}\text { Egy folyamathoz több modult kell használni, amikbe külön- } \\
\text { külön be kell lépni }\end{array}$ \\
\hline \multicolumn{2}{|l|}{ Standard riportok futtatása } \\
\hline & Nagyszámú adat feltöltése irreálisan sok időt vesz igénybe \\
\hline
\end{tabular}


A Gammánál az anyavállalati vállalatirányítási rendszert vezették be. A cégszintű alkalmazás fejlesztője egy indiai vállalat (kiszervezés keretében), ahol dedikált emberek dolgoznak együtt a Gamma felhasználóival. A Gamma helyi IT-funkciójának feladata tulajdonképpen a fejlesztési igények összehangolása, és a kommunikáció javítása az üzleti és fejlesztői csapatok között.

A vállalt és elvárt szolgáltatási színvonal folyamatos tartása miatt az időzítések és a megfelelő információ folyamatos közvetítése kulcsfontosságú. A kivételek kezelése (leggyakrabban egy sürgős, vagy soron kívüli szállítmány, vagy egy elveszett anyag ügye) különösen intenzív együttmüködést igényel.

„Lehet a szolgáltatási színvonalad 99\%-os, de a vevö nem lesz elégedett, ha nem segitesz neki a sürgös esetekben. Ha csak 80\%-on teljesitesz és gyorsan megoldasz neki egy sürgős szállitmányt, a vevö sokkal elégedettebb lesz!"

(Gamma ügyvezetője)

Az 1. táblázatban összefoglaltam, hogy Béta, illetve Gamma esetében milyen vállalati igények, illetve felhasználói „panaszok” alakultak ki.

Ezekkel a kihívásokkal szemben a felhasználókat helyi szakértők segítették. Informálisan - majd később ezek a pozíciók valamilyen formában formálissá váltak - a társas kapcsolatokon keresztül bizonyos felhasználók a rendszeren kívül, vagy a rendszeren belül megoldásokat tudtak nyújtani a felhasználók igényeire.

\section{A helyi IT-szakértôk bemutatása}

A BÉTA vállalatnál a kezdeti zöldmezös beruházás idején egy maroknyi mérnökcsapat alakította ki az alapokat mind a termelés, mind a kapcsolódó anyagi folyamatok területén. Ök működtek közre az IT-rendszer bevezetésénél is. Rövid időn belül kiderült, hogy a rendszer nem támogatja a munkájukat megfelelően, így „okos” megoldásokat találtak ki: vagy a rendszer mellett, vagy a rendszert trükkökkel alakítva. Ebben az egyik élenjáró mérnök $\mathrm{S}$. T. volt, aki kezdetben fejben, majd Excelben szervezte a gyártást és alapanyag-ellátást, de ezzel párhuzamosan - föleg a pénzügyi beszámolási kötelezettséghez kapcsolódó kényszer hatására - sok mindent felfedezett és megoldott a rendszeren belül is. Jól mutatja kísérletező kedvét, ahogyan egy rendszerbeállításra vonatkozó kérdésemre válaszolt:

„Nem tudom, ezen még nem gondolkoztam, de jó ötletnek tünik. Ma délután munkaidő után kipróbálom: futtatok egy tesztet ezzel a beállítással."
S. T. az ügyvezetővel együttműködve egy gyártási segédprogramot is kifejlesztett.

„A készletek alacsony szintje kulcs, mivel a nyersanyagok a legföbb költségtényezök. A beérkezö megrendelések tapasztalataink alapján nagyjából 50\%-os pontosságúak. Ez nagyon magas készletszintet eredményezne, nem engedhetjük meg magunknak."

„A készletszint optimalizációjához ki kell simitani a beérkezö rendelések hullámzását. Ennek megoldására S. T. six sigma elveket felhasználva kialakitott egy ITO (inventory turn optimalization, készletforgás optimalizáció) táblát Excel-ben. A rendszerböl letöltött riportot felhasználva különbözö matematikai és statisztikai módszerekkel (normálás, szórásátlag) simitja ki a beérkezö megrendeléseket, és egyenletesebb beszerzési igényekké alakitja öket. Ezt a folyamatot - és a hozzá szükséges megkerülö rutint - a magyar vezetöség bemutatta a vállalatcsoport igazgatósági megbeszélésén és azóta vállalatcsoport-szinten használják az egész világon."

(Béta ügyvezető igazgatója)

Fontos kiemelnem, hogy a fenti idézet az ügyvezető igazgatótól arra is rámutat, hogy az általa vezetett cég helyi kultúrája igencsak támogatta, elismerte, sőt, elösegítette a kísérletezést, az okos megoldásokat. Ő maga kezdeményezett nem egy rendszeren kívüli, kétségtelenül igen kreatív megoldást, bár nem ő fejlesztette ki azokat.

Sz. Z. informatikus később csatlakozott a vállalathoz. Ö következetes folyamatokat és szabályokat, biztonsági intézkedéseket vezetett be. Emiatt és távolságtartóbb személyisége miatt nem igen fogadták el a felhasználók, így nem fordultak hozzá problémáikkal. Ö nem is igyekezett minden felhasználói igényt kielégíteni:

„Az ERP-rendszerek standard folyamatokkal és standard riportokkal dolgoznak. Normális, hogy a rendszer nem képes kielégiteni minden felhasználói kivánságot. Meg tudom érteni, hogy mindenki mindent mindenféle bontásban akar látni, de ha valakinek hirtelen kipattan egy ötlet a fejéböl, azt csinálja meg inkább Excelben egy workarounddal."

Minden fejlesztést (melyet formális folyamaton keresztül, üzleti indoklással lehetett igényelni) hivatalos, nemzetközi csatornákon hajtott végre. Ezek természe- 
tesen lényegesen több időt vettek igénybe, mint a helyi „barkácsolt” megoldások, amikhez mindenki hozzá volt szokva. Munkája és hozzáértése miatt nagyon rövid időn belül regionális felelősséget is kapott, de mivel a helyi csapat egyáltalán nem fogadta el őt, az utókövető interjúk idején már nem dolgozott a cégnél.

Több igényröl, szabálytalan rendszeren kívüli megoldásról a velem végzett interjúban hallott elöször. Kérdésemre elmondta:

„A többségükröl nem tudtam. Nem vontak bele ezekbe, pedig többször kértem. Bár részt vettem a vezetöségin, ott csak a mutatószámokon mentek végig, a folyamatbeli változásokat nem ott beszélték meg, hanem külön. Hozzám sosem értek el ezek a dolgok."

A GAMMA vállalatnál N. L. először készletszint-tervezőként dolgozott, majd megüresedésekor átvette az informatikusi feladatokat. Mivel alaposan értette az üzleti folyamatokat és felhasználói igényeket is, sok megoldással ő állt elö, illetve igyekezett segíteni, képviselni a felhasználókat különböző fórumokon.

\begin{abstract}
„Ez egy Excel makró. Láttam, hogy a többiek sokat szenvednek a cikkszámok feltöltésével. Megkérdeztem, mi a pontos folyamat és irtam rá egy makrót. Mivel a makró tulajdonképpen a gépelést szimulálja, sok más dologra is írtam már makrót. Most például az új vevö projektjénél a raktári beérkeztetést szimuláltuk, mert olyan sok áru érkezett be egyszerre."
\end{abstract}

P. J. raktárosként dolgozott a Gammánál. Nagyon elkötelezett és ambiciózus volt, igyekezett a vezetöség kedvében járni. Ennek megfelelően betartotta a folyamatokat, és a rendszerhez való alaposabb értését is felhasználta, hogy egy-egy problémát megoldjon. A kutatás ideje alatt vezették be a raktározási folyamatok optimalizálása keretében a félig dinamikus tárhelyek rendszerét. P. J.-nek ehhez kapcsolódóan sok pluszmunkája volt, ő volt az, aki manuális munkával, külön táblázatok elkészítésével és kitöltésével támogatta a sikeres bevezetést. A többi raktáros azonban nem érdeklödött a rendszer használata, rejtelmei iránt. Értékelték, hogy P. J. megoldja ezeket a problémákat, így nem is foglalkoztak a rendszerrel. A saját feladataikhoz szükséges IT-lépéseket mechanikusan elvégezték, de nem folytak bele a projekthez kapcsolódó új folyamatokba, felfedezésekbe. Így bár a többiek is követték az új folyamatokat, nem vették át az ő megoldásait.

\begin{abstract}
„Minden hétfón lefuttatok egy riportot a rendszerben, hogy melyik tárhelyen van nulla darab cikkszám. Ezeket a tárhelyeket használjuk azon a héten, amig van. Én mondom a fiúknak, hogy hova tárolják be az új anyagokat, és én is kezelem a papirlapot. Ha elfogy az üres hely, futtatok még egy riportot. A többiek inkább nem piszkálják a gépet."
\end{abstract}

\section{A helyi IT-szakértő́k szerepe}

A következőkben Birkinshaw, Hamel és Mol (2008) által azonosított négyes változásvezetési szempontrendszert az informatikai bevezetésekre alakítva használom az egyes hozzáértő felhasználók szerepének bemutatására és elemzésére.

1. Motiválás - mennyiben befolyásolták az egyes szereplők a rendszer használatának körülményeit, mennyiben tudtak olyan környezetet teremteni, amiben a rendszert használni tudták és akarták a felhasználók?

Ezt a szempontot úgy érem nyomon, hogy vizsgálom, milyen erőfeszítéseket tett az egyén az oktatás, betanítás és fogások, trükkök megosztása terén a többi felhasználóval.

2. Kisérletezés - kísérletezés a rendszer lehetöségeivel. A szempont vizsgálatakor arra vagyok kíváncsi, hogy mennyire próbált ki saját újításokat a rendszerrel - problémák megoldására, vagy a saját tudása bővítésére. A feltárt workaround-ok vizsgálata sokat segíthet ezen a területen.

3. Bevezetés - a folyamatok alakítása, befolyásolása: a rendszer, vagy az újítások bevezetésekor a kapcsolódó folyamatokat, esetleg munkaköröket, felelösségeket, más rendszereket is alakítani szükséges. Ebben milyen szerepe jut az azonosított helyi szakértőnek?

4. Az újitás értelmezése - az új rendszer, vagy rendszerelem bevezetésekor szükséges annak magyarázata, értelmezése a többi felhasználó felé. Az együttdolgozás során kialakított magyarázatok és narratívák, ahogy a helyi szakértő nyilatkozik, beszél a rendszerröl meghatározhatja, vagy befolyásolja, ahogyan a többség rendszerértelmezése alakul.

A 2. és 3. táblázat segítségével áttekintem, hogy a bemutatott négy szerepet mennyiben és milyen módon töltik be az azonosított helyi szakértők. A jobb áttekinthetőség kedvéért vállalatonként külön készítettem el a táblázatot. 


\section{Az azonosított helyi szakértő́k szerepe a változásvezetésben: Béta vállalat}

\begin{tabular}{|c|c|c|}
\hline Béta vállalat & S. T. & Sz.Z. \\
\hline Motiválás & $\begin{array}{l}\text { Felhasználói kézikönyvet és útmutatót készített, de } \\
\text { tréningeket nem szerveztek. Elérhetővé tette, bár } \\
\text { aktívan nem segítette elő a rendszer használatát. } \\
\text { Inkább ő maga keresett megoldást. }\end{array}$ & $\begin{array}{l}\text { Nem érezte magáénak a feladatot, hogy a } \\
\text { munkatársakat meggyőzzze, az ügyvezetőre } \\
\text { hagyatkozott ezen a területen. }\end{array}$ \\
\hline Kísérletezés & $\begin{array}{l}\text { Kiemelkedő szempont: folyamatosan kísérletezett, } \\
\text { akár az adatintegritást is kockáztatta egy-egy } \\
\text { megoldás kedvéért. }\end{array}$ & $\begin{array}{l}\text { Ismerte a rendszert, nem próbálgatott. A } \\
\text { szabályok, standard folyamatok, múködési } \\
\text { biztonság voltak a legfontosabbak. }\end{array}$ \\
\hline Bevezetés & $\begin{array}{l}\text { Az újrabevezetési csapat tagja, jól felhasználható } \\
\text { részletes tudása a vállalati szükségletekről. }\end{array}$ & $\begin{array}{l}\text { Professzionálissá teszi a rendszer használatát és } \\
\text { beállításait. Hozzáférési jogokat szabályozza, } \\
\text { több standard folyamatot vezet be. Ezek inkább } \\
\text { korlátozó szabályok, mint elősegítés. }\end{array}$ \\
\hline $\begin{array}{l}\text { Az újítás } \\
\text { értelmezése }\end{array}$ & $\begin{array}{l}\text { Az első bevezetés kapcsán nagyon meghatározó } \\
\text { egyéni értelmezése. Az ő megoldásai, ismeretei } \\
\text { nyújtanak segítséget a legtöbb komplex esetben. }\end{array}$ & $\begin{array}{l}\text { A rendszernek szigorú értelmezést ad, „felsőbb } \\
\text { erő” aminek engedelmeskedni kell - ez az } \\
\text { értelmezés Béta kultúrájában nehezen elfogadható, } \\
\text { nem népszerú. }\end{array}$ \\
\hline
\end{tabular}

Az azonosított helyi szakértők szerepe a változásvezetésben: Gamma vállalat

\begin{tabular}{|c|c|c|}
\hline Gamma vállalat & N. L. & P. J. \\
\hline Motiválás & $\begin{array}{l}\text { Sokat tett a rendszer használatáért, oktatásokat } \\
\text { tartott, mindig, mindenkinek készségesen } \\
\text { elmagyarázott mindent részletesen. Sok trükköt, } \\
\text { fogást osztott meg a kollégákkal. }\end{array}$ & $\begin{array}{l}\text { A csapat tagjai nem érdeklődtek a rendszer } \\
\text { használata iránt - nem is volt célja és nem is tudta } \\
\text { felkelteni az érdeklődést. Átfogóbb problémákat } \\
\text { nem tudott megoldani, ő is és a többiek is N. } \\
\text { L-hez fordultak inkább. }\end{array}$ \\
\hline Kísérletezés & $\begin{array}{l}\text { Alaposan ismerte a rendszert, a múködési } \\
\text { logikáját. Több mások által nem ismert funkciót } \\
\text { is használt. Kifejlesztett újításokat, amiket széles } \\
\text { körben használtak. }\end{array}$ & $\begin{array}{l}\text { Csak nagyon kis léptékben, a feladathoz szorosan } \\
\text { kapcsolódóan próbálgatott - nem igazan jellemzô. }\end{array}$ \\
\hline Bevezetés & $\begin{array}{l}\text { Szakszerúen bevezetett újításokat, amiket } \\
\text { hivatalosan is fejlesztettek. A folyamatokat ennek } \\
\text { megfelelően alakította. }\end{array}$ & $\begin{array}{l}\text { Nem volt befolyása átfogó folyamatokra, } \\
\text { átfogó rendszerlogikát már nem értett. Saját } \\
\text { munkaköréhez kapcsolódóan hozott változásokat } \\
\text { az újításoknak megfelelően. }\end{array}$ \\
\hline $\begin{array}{l}\text { Az újítás } \\
\text { értelmezése }\end{array}$ & $\begin{array}{l}\text { Meghatározó volt véleménye és szakértelme } \\
\text { a teljes cégnél. Ó szolgált magyarázatokkal, } \\
\text { értelmezésekkel, amit többnyire általánosan } \\
\text { elfogadtak. }\end{array}$ & $\begin{array}{l}\text { A raktáron belüli IT-hozzáértésével azt vívta ki, } \\
\text { hogy ő kezelte a rendszert, a többiek ráhagyták a } \\
\text { bonyolultabb folyamatokat. Nem volt érdeklődés. }\end{array}$ \\
\hline
\end{tabular}

\section{Összegzés}

A fentiek alapján a helyi IT-szakértők szerepére vonatkozóan az alábbi következtetéseket vonhatjuk le:

A (1) motiválás szempontjából a helyi IT-szakértők csak keveset tudtak tenni. A valódi használathoz és a felhasználás fegyelméhez (Bartis, 2014) kulcsfontosságú a vezetőség és az egyes közvetlen vezetök elkötelezettsége. Amennyiben ez nem része a kultúrának (mint például Béta esetében a kezdeti időkben), vagy a vezetők nem kérik számon a rendszer precíz használatát, akkor a munkavállalók csak a számukra hasznos lépéseket fogják megtenni (lásd Poelmans (1999) által bevezetett viszkozitás fogalma). Ezt mutatja Gamma raktárának helyzete, ahol a vezetőség számára nem volt jelentősége, hogy minden egyes raktáros kövesse az új folyamatot, vagy egyetlen raktáros hajtja végre mindenki helyett.

Eszerint a formális hatalom támogatásának nagy jelentősége van a rendszer használatának szempontjából.

Amennyiben a formális hatalom normái (Béta) és elvárásai (Gamma) alapján a rendszert használni kell, akkor kerülnek elötérbe azok a módszerek, fogások, trükkök, amik a felhasználók napi gondjain segítenek. 
Ebben az esetben a helyi szakértők adhatják meg azt a segítséget, amivel a rugalmatlanul felépített rendszer a helyi viszonyokhoz, az egyéni feladatokhoz alakítható (Bartis, 2014).

A (2) kisérletezés Béta alapítását követően igen messzire ment - azért történhetett meg mindez, mert a korai céges kultúrában az adatok integritása nem volt fontos szempont. Így S. T. gyakorlatilag (teljes rendszergazdai hozzáférés birtokában) bármit kipróbálhatott, formális korlátai nem voltak. Sőt, amennyiben valamilyen problémát nem tudtak megoldani, hozzá fordultak és elfogadták a kreatív, rövid távú megoldásokat. Például váltogatta a rendszeridőt, hogy többféle valuta-árfolyammal tudjanak számolni a havi beszámolókban.

A rendszer újrabevezetése, illetve Sz. Z. érkezése ennek vetett véget. Sz. Z. azonnal szabályozni kezdte a hozzáférési jogokat, és nem nyújtott azonnali megoldásokat a felhasználók problémáira, hanem a rendszer (nehézkes) használatát javasolta helyette.

A kísérletezés Gammánál (majd az újrabevezetés és a hozzáférési jogok szabályozása után Bétánál is) sokkal kisebb szabadságfokkal történt. Sokkal inkább jelentette ez azt, hogy a rendszert jól ismerő helyi szakértők segítettek eldönteni, hogy milyen hivatalos fejlesztés lehetséges - a formális IT vezetöi szerep részeként, vagy projektmunkába bevonva. Amennyiben hivatalos megoldásra nem volt kilátás, akkor segítettek egy adatintegritást nem veszélyeztető rendszeren kivüli megoldást találni a problémára. Fontos kiemelni, hogy a kísérletezés eredményeként csak akkor születnek fenntartható megoldások, ha azok az adatintegritást nem érintik.

(3) Bevezetés kapcsán megállapíthatjuk, hogy a rendszer bevezetését a hozzáértő szakemberekre bízza a vezetőség. Béta esetében Sz. Z. 3 hónappal belépése után már regionális vezetői pozíciót kapott a vállalatcsoportban szakértelme alapján.

S. T.-t - mérnöki jellegü munkaköre mellett is - az újrabevezetést irányító projektcsapat egyik vezetőjévé nevezte ki az ügyvezetö. Gammánál pedig N. L.-t nevezték ki IT-vezetőnek, amikor a pozíció megüresedett, bár előtte az operációban dolgozott.

Mind S. T. és N. L. esetében kiemelték a vezetők, vagy kollégák, hogy a választás nagyon jónak bizonyult, hiszen a korábbi IT-szakértő a sok informális kapcsolatán keresztül részletesen tisztában van a felhasználói szükségletekkel, a folyamatok részleteivel.

Fontos az is, hogy a hozzáértésnek meggyözönek kell lennie: a Gamma raktára esetében láthattuk, hogy P. J. affinitása nem elegendő szakértelem, mivel a rendszerlogikát átfogóan nem ismerte. Így a fizikai távolság (másik épület) ellenére is N. L-hez fordultak a raktárosok, ha segítségre volt szükségük.
(4) Az újitás értelmezése - Az új rendszer vagy rendszerelem bevezetésekor szükséges annak magyarázata, értelmezése a többi felhasználó felé. Az együttdolgozás során kialakított magyarázatok és narratívák, ahogy a helyi szakértő nyilatkozik, beszél a rendszerről meghatározhatja vagy befolyásolja azt, ahogyan a többség rendszerértelmezése alakul.

A helyi IT-szakértő személyisége meghatározó tényezőnek bizonyult. Azok a helyi IT-szakértők tudták befolyásolni a használatot, akik nyitottak voltak meghallgatni a felhasználók problémáit. Sem P. J. a Gammánál, sem Sz. Z. a Bétánál nem tudta a többiek használatát befolyásolni - az ő értelmezésük nem érte el a felhasználókat.

P. J. (Gamma) esetében már tárgyaltuk a lehetséges okokat - a szakértelme nem volt teljesen meggyőző. Sz. Z. (Béta) esetében észrevehetö, hogy a segitökészség hiánya - az igyekezet, hogy a szakértő megértse és elfogadja a felhasználók szükségleteit - miatt nem keresték meg a problémáikkal és nem is követték tanácsait. Az interjú során több felhasználói igényről tőlem értesült, az általam feltárt workaround-ok többségéről pedig egyáltalán nem tudott. Kitünt szóhasználatából, hogy kissé lenézi a felhasználókat (például: „,butuskák”, vagy „,be kellene már látniuk...”).

Ellentétben, N. L. kifejezetten kereste azokat a helyzeteket, ahol segíthet. A felhasználók panaszait a legmagasabb fórumokig elvitte, mérésekkel igazolta.

Hasonlóan, S. T. kapcsán a legtöbb felhasználó megemlítette, hogy magáévá tette a többiek ügyes-bajos dolgait és nem nyugodott, amíg valamilyen megoldást nem talált.

Összességében elmondható, hogy S. T. (Béta) és N. L. (Gamma) Orikowski és társai (1995) által leírt technológiamediátorként müködtek, hiszen informálisan segítették munkatársaikat. Érdekes, hogy mindkét szakértő szerepe később valamilyen formában formálissá is vált - rámutat arra, hogy a helyi szakértők értékes tudással és elismert szereppel rendelkeznek.

Hozzáértésük elegendő is volt ehhez - ami P. J-nél (Gamma) nem érte el azt az átfogó szintet, így ő nem tudta befolyásolni érdemben a kialakuló használatot. Sz. Z. (Béta) esetében pedig a hozzáértés igencsak megvolt, ezt bizonyítja, hogy nagyon rövid időn belül regionális felelösséget kapott, azonban helyi szinten nem volt megközelíthető a kollégák számára. Így azok nem avatták bizalmukba, nem alakult ki olyan kapcsolat közte és a szervezet tagjai között, hogy módszereit átvegyék.

\section{Következtetések}

A fentiekben áttekintett szempontok alapján levonható néhány olyan következtetés, amelyeket a korábbi szak- 
irodalom nem jegyez. Kutatásom eredményeként az alábbi föbb megállapitásokat emelem ki:

1. A helyi IT-szakértő akkor tudja hatékonyan befolyásolni a rendszerhasználatot, ha informálisan is megfelelö kapcsolatot tud kialakítani a felhasználókkal. Itt nem elsősorban a közkedveltség bizonyul fontos tényezőnek, hanem a segítőkészség. Két komponensét azonosítottam ennek az attitüdnek: az igyekezet, hogy a felhasználók gondjain segítsen a szakértő, illetve, hogy ezek a megoldások valódiak legyenek: beváljanak, és valóban megoldást nyújtsanak az adott problémára - a felhasználók szemszögéből.

2. Újítások csak akkor terjednek el, ha azok vagy jelentősen megkönnyítik az egyéni felhasználó munkavégzését, vagy formálisan kötelezővé teszik és ellenőrzik. A helyi IT-szakértőnek - informális szerepben - az elöbbiben jelentős a befolyása.

2. Helyi IT-szakértővé akkor válhat valaki, ha:

a. hozzáértő, jól ismeri a rendszer müködési logikáját és természetes kíváncsiság hajtja,

b. megközelíthető és segítőkész személyisége van,

c. hosszabb távon pedig automatizált, az adatintegritást tiszteletben tartó megoldásokat épít.

A fenti elemek mindegyikére szükség van ahhoz, hogy az adott hozzáértő felhasználóból mások rendszerhasználatát befolyásoló „helyi IT-szakértő” váljék.

Cikkem feltárja és tisztázza a kapcsolatot a társas befolyásolás kapcsán azonosított szerepek között és igyekszik tisztázni, hogy milyen tényezők esetén milyen befolyással bírhatnak az egyes helyi IT-szakértők.

Következtetéseim megbízhatóságát erősíti, hogy azok logikusan kapcsolódnak mind Handy és Barlow (2012), mind pedig Woodford (2014) következtetéseihez, azokat kiegészítik.

\section{Felhasznált szakirodalom}

Atkinson, R. - Crawford, L. - Ward, S. (2006): Fundamental Uncertainties in Projects and the Scope of Project Management. International Journal of Project Management, 24.,8, p. 687-698.

Bartis Eszter (2014): Az interpretatív rugalmasság eszközei: az információs rendszeren kívüli felhasználói rutinok. PhD-értekezés. Budapest: Budapesti Corvinus Egyetem

Bjorn-Andersen, N. - Eason, K. - Robey, D. (1986): Managing Computer Impact. Norwood, NJ: Ablex Publishing
Culnan, M. J. (1983): Chauffeured Versus End-User Access to Commercial Databases: the effects of tasks and individual differences. MIS Quarterly, 7,1, March, p. 56-67.

Dobák Miklós (1996): Szervezeti formák és vezetés. Budapest: AULA Kiadó

Dobson, S. - Fitzgerald, L. - Ferlie, E. - Gabbay, G. Locock, L. (2010): No Magic Targets!

Changing Clinical Practice to Become More Evidence Based. Health Care Manage Review, 35, (1), p. 2-12.

Ferneley, E. - Sobreperez, P. (2006): Resist, Comply or Workaround? an examination of different facets of user engagement with IS. European Journal of Information Systems, Vol 15, p. 345-356.

Hendy, J. - Barlow, J. (2012): The Role of the Organizational Champion in Achieving Health System Change. Social Science \& Medicine, 74(3), p. 348355.

Howell, J. M. - Shea, C. M. - Higgins, C. A. (2005): Champions of Product Innovations: defining, developing, and validating a measure of champion behavior. Journal of Business Venturing, 20 (5), p. 641-661.

Kerzner, H. R. (2013): Project Management: a systems approach to planning, scheduling, and controlling. Chichester: John Wiley \& Sons

Mackay, W. E. (1990): Users and Customizable Software: a co-adaptive phenomenon. Ph.D. dissertation. Cambridge, Mass.: MIT Sloan School of Management

Obal, M. - Ibrahim, S. (2016): An Investigation on the Role of Disruptive Technology Adoption on New Product Market Performance and Launch Timeliness. in: Let's Get Engaged! Crossing the Threshold of Marketing's Engagement Era. Heidelberg: Springer International Publishing, p. 523-524.

Orlikowski, W. J. - Yates, J. et al. (1995): Shaping Electronic Communication: the metastructuring of technology context in use. Organization Science, 6(4), p. 423-444.

Pfeffer, J. (1981): Management as Symbolic Action: the creation and maintenance of organizational paradigms. Research in Organizational Behavior, 3, p. $1-52$.

Salovaara, A. - Helfenstein, S. - Oulasvirta, A. (2011): Everyday Appropriations of Information Technology: a study of creative uses of digital cameras. Journal of the American Society for Information Science and Technology, 62,12, p. 2347-2363.

Soo, S. - Whitney, B. - Baker, R. (2009): Role of Change Champions in the Implementation of Patient Safety Practice Change. Healthcare Quarterly, 12, p. 123-128. 
Thomas, J. - Griffin, R. (1983): The Social Information Processing Model of Task Design: a review of the literature. Academy of Management Review, 8,4, p. 672-682.

Woodford, N. (2014): Administrator Responses to Technology Leadership: navigating the revised learning and technology policy framework.
Yang, Z. - Ng, B. Y. - Kankanhalli, A. - Yip, J. W. L. (2012): Workarounds in the Use of IS in Healthcare: a case study of an electronic medication administration system. International Journal of Human-Computer Studies, 70(1), p. 43-65.

Zhang, W. et al. (2011): Social Influencing and Associated Random Walk Models: asymptotic consensus times on the complete graph. Chaos: An Interdisciplinary Journal of Nonlinear Science, 21.2: 025115 